\title{
Tudomány és oktatás a digitális korban
}

\section{A felsőoktatási könyvtárak stratégiai fejlesztési irányai 2018-2023}

Az Egyetemi Könyvtárigazgatók Kollégiuma (EKK) a felsőoktatási könyvtárak vezetőit tömörítő, egyesületi formában működő szakmai civil szervezet. 1992-es alapítása óta célja, hogy segítse a felsőoktatási könyvtárak müködését, az egyetemi oktatást-kutatást támogató szolgáltatásaik színvonalának emelését. Az effajta elvont célokat azonban az EKK is, mint minden szervezet csak átgondoltan, a mindenkori helyzetet számba véve, rövid- és középtávú cselekvési irányok kijelölése révén tudja megvalósítani.

Részben ezért, részben a felsőoktatás és benne a könyvtárak müködését jelentősen befolyásoló változás, a kancellári rendszer 2014. évi bevezetése miatt a szervezet 2016-ban szükségesnek ítélte egy középtávú stratégia kidolgozását. Az első vázlatos javaslat némi módszertani vitát indukált a következő kérdésekkel: kinek a stratégiája - az egyesületé vagy a könyvtáraké, lehet-e stratégiát írni intézkedések és források hozzárendelése nélkül, és így tovább. Végül az az elhatározás született, hogy felvázoljuk a felsőoktatási könyvtárak általános középtávú fejlődési-fejlesztési irányait, majd javaslatot teszünk a felsőoktatásért és a közgyüjteményi területért felelős kormányzati szerveknek a célok elérését biztosító intézkedésekre.

Ennek az elhatározásnak a nyomán indult el a munka, amiben támogató segítséget kaptunk az EMMI felsőoktatásért felelős helyettes államtitkárától és munkatársaitól, valamint az EMMI Közgyüjteményi Főosztályától.

A javaslat a felsőoktatási könyvtárak alapértékeinek meghatározásával, a középtávú jövőkép felvázolásával és a küldetés megfogalmazásával kezdődik. A fejlesztési irányok kijelölése a nemzetközi tendenciák feltérképezésén, a jelenlegi helyzet elemzésén, a kormány által elfogadott, releváns nemzeti stratégiák ${ }^{1}$,

${ }^{1}$ Fokozatváltás a felsőoktatásban. Középtávú szakpolitikai stratégia, 2016. https://www. kormany.hu/download/b/fa/ $11000 /$ EMMI\%20 fokozatv $\%$ C $3 \% \mathrm{~A} 11 \mathrm{t} \% \mathrm{C} 3 \% \mathrm{~A} 1 \mathrm{~s} \% 20$ fels\%C $\% \% 91$ oktat $\%$ C3 $\%$ A 1 s $\% 20$ cselekv\%C3\%A 9si $\% 20$ terv $\% 20$ Sajt $\%$ C3 $\%$ B 3 \% 20 \%C3\%A9s\%20Kommunik\%C3\%A1ci\%C3\%B3s\%20F\%C5\%91oszt\%C3\%A1ly\%2020170627. pdf (2018. szeptember 20.); Befektetés a jövőbe. Nemzeti Kutatás-fejlesztési és Innovációs Stratégia (2013-2020). https://nkfih.gov.hu/hivatalrol/nemzeti-kfi-strategia/befektetes-jovobe-kfi (2018. szeptember 20.); Digitális Jólét Program 2.0, Magyarország Digitális Oktatási Stratégiája. https:// www.kormany.hu/download/0/cc/d0000/MDO.pdf (2018. szeptember 20.); Nemzeti Infokommunikációs Stratégia, 2014-2020. https://www.kormany.hu/download/a/f7/30000/ NIS_v\%C3\%A9gleges.pdf(2018. szeptember 20.); Közgyüjteményi Digitalizálási Stratégia, 2017- 
valamint az ezekben megfogalmazott célok számbavételén, és a kapcsolódási pontok meghatározásán alapul.

A fejlesztési koncepciót felvázoló anyag előkészítését, a kérdőív kidolgozását és elemzését, a szöveg összeállítását öten végeztük: Antal Istvánné (EMMI Közgyüjteményi Főosztály), Kálóczi Katalin (ELTE Egyetemi Könyvtár és Levéltár), Karácsony Gyöngyi (Debreceni Egyetem Egyetemi és Nemzeti Könyvtár), Keveházi Katalin (Szegedi Tudományegyetem Klebelsberg Könyvtár) és magam (Nagy Zsuzsanna, Budapesti Corvinus Egyetem Egyetemi Könyvtár). A fejlesztési irányok meghatározása, a SWOT-elemzésben felsorolt tényezők azonosítása és a szükséges intézkedések kijelölése azonban az EKK-tagok közös szellemi termékének tekinthető.

A következő elképzelések részletesebben olvashatók A felsőoktatási könyvtárak stratégiai fejlesztési irányai 2018-2023 című anyagban, ami megtalálható az EKK honlapján. ${ }^{2}$

\section{Az egyetemi könyvtárak alapértékei}

A felsőoktatási könyvtárak alapértékeiként a következő főbb területeket azonosítottuk.

1. A társadalom és a gazdaság, benne az egyének és közösségek fejlödésének elősegítése a magas színvonalú tudományos információhoz való minél szélesebb körü hozzáférés biztosításával.

2. A tudás, a tanulás és az innováció előmozdítása.

3. A felhasználók legmagasabb szintü kiszolgálása.

4. Szakmailag elkötelezett, etikus és felelős munkavégzés.

5. A demokrácia, a nyitottság és az együttmüködés tisztelete.

\section{Jövőkép}

A felsőoktatási könyvtárak a 2020-as évek elején:

- a dinamikusan fejlődő, teljesítményelvü felsőoktatás, valamint a hálózatosodó tudományos kutatási és innovációs intézményrendszer kulcsszereplöi;

- a digitális gyüjtemények építésével vezető szerepet játszanak a tudományos eredmények megőrzésében és disszeminációjában;

- az innovatív tudományos kommunikáció és a nyitott tudomány támogatásával segítik a magyar tudomány nemzetközi versenyképességét;

2025. https://www.kormany.hu/download/9/ac/11000/K\%C3\%B6zgy\%C5\%B1jtem\%C3\%A9nyi \%20Digitalizl\%C3\%A1si\%20Strat\%C3\%A9gia_2017-2025.pdf (2018. szeptember 20.)

${ }^{2}$ A felsőoktatási könyvtárak stratégiai fejlesztési irányai, 2018-2023. Az Egyetemi Könyvtárigazgatók Kollégiumának javaslata. http://ekk.org.hu/sites/default/files/EKFJ_2018_2023a.pdf (2018. szeptember 20.) 
- a digitális készségek és szolgáltatások fejlesztésének hálózati csomópontjai;

- az átvihető készségeket fejlesztő képzési programjaikkal és személyre szabott szolgáltatásaikkal támogatják a tudásátadást, és képessé teszik a tudományos közösség tagjait, köztük a hallgatókat is, felelősségteljes új tudás létrehozására és disszeminációjára;

- széles spektrumú szolgáltatásaik és korszerüen felszerelt tanulási és közösségi tereik révén hozzájárulnak a hallgatói eredményességhez, növelik a felsőoktatási intézmények aktivitását a társadalmi kihívások kezelésében és a társadalmi innováció terjesztésében;

- a nyomtatott és digitális nemzeti kulturális örökség hozzáférhetővé tételének és megőrzésének kulcsszereplői.

\section{Nemzetközi tendenciák}

A nyugat-európai és észak-amerikai egyetemi könyvtári stratégiák áttekintése után kijelenthetjük, hogy kevés nemzeti szintű példát találni. Ảltalánosságban mégis kiemelhető néhány, a felsőoktatási és tudományos könyvtárakra jellemző törekvés és irányvonal. ${ }^{3}$ Beágyazott könyvtárakról van szó, amelyekben a könyvtár által nyújtott szolgáltatások az intézményi célokat szolgálják, és partneri viszonyon alapulnak az oktatókkal, kutatókkal, hallgatókkal. Általános törekvésként jelenik meg a virtuális oktatási-kutatási környezet kialakítása, az elektronikus tartalomfejlesztés támogatása, a nyílt hozzáférés térnyerésének elősegítése a repozitóriumi infrastruktúra müködtetésével, és az innovatív tudományos kommunikáció támogatásával. A hallgatók tanulmányi sikerességét segítő moduláris képzési programok, továbbá a fizikai és virtuális könyvtári terek mint „tanulási csomópontok” (learning hub) egyaránt jól példázzák a könyvtári szolgáltatásokban rejlő hozzáadott értéket. A könyvtárosok kompetenciáinak folyamatos fejlesztése, a hatékony kommunikáció és menedzsment világszerte elengedhetetlen feltétele a könyvtárak sikeres müködésének.

\section{Helyzetelemzés}

A fejlesztési irányok és feladatok kijelöléséhez szükséges helyzetelemzés keretében a következő elemzési technikákat alkalmaztuk: kérdőíves felmérésen alapuló erőforrás-elemzés, a környezeti hatásokat számba vevő PGTTJ-elemzés, Porterféle versenyerő-modell, BCG mátrixon alapuló portfólió elemzés, SWOT-elemzés.

\footnotetext{
${ }^{3}$ Koren, Marian: Libraries in the Netherland. 2016. http://www.fobid.nl/sites/fobid/files/Libraries\%20in\%20the $\% 20$ Netherlands\%2C\%20Koren\%202016.pdf (2018. szeptember 20.); The academic library on its way to 'the cloud'. UKB strategic plan 2011-2015. 2011. https://www.ukb.nl/ sites/ukb/files/docs/UKBStrategicPlan2011-2015.pdf (2018. szeptember 20.); Powering scholarship. RLUK strategy 2014-2017. https://www.rluk.ac.uk/wp-content/uploads/2014/02/RLUK-Strategy2014-online.pdf (2017. október 10.)
} 
A kérdöíves felmérés kitért a könyvtáraknak az egyetemi struktúrában való elhelyezkedésére, fizikai infrastruktúrájára, informatikai felszereltségére, szolgáltatásaira, humánerőforrásaira és állományára. Az erőforrás-elemzés alapján megállapítható, hogy hagyományaik, fizikai és humán meghatározottságuk, a fenntartó által kijelölt céljaik és lehetőségeik, földrajzi és társadalmi beágyazottságuk szerint jelentősen különböző könyvtárakról van szó. A magyar könyvtári rendszerben és felsőoktatásban azonban meghatározó a szerepük, az épített és informatikai infrastruktúrájuk, egyedi értékű gyűjteményeik, humánerőforrásaik és a célközönségnek, illetve a tágabb közösségnek nyújtott szolgáltatásaik nem csak elérik a kritikus tömeget, de mindkét szektor számára nélkülözhetetlenek. A különbségek ellenére összességében korszerü szolgáltatáspalettát kínáló, sok területen alulfinanszírozott, vegyes fizikai terekkel, közepesen elavult informatikai felszereltséggel és együttmüködésre nehezen képes könyvtári informatikai rendszerekkel müködő intézményhálózatról beszélhetünk. Komoly problémát jelent a megfelelő tudással és készségekkel rendelkező munkaerő felvétele és megtartása is.

A további elemzési módszerek eligazítást adnak a működést meghatározó jelenlegi és várható viszonyokról, a fő versenytársakról, a szolgáltatási portfólióban rejlő lehetőségekről, a könyvtárak azon erősségeiről és lehetőségeiről, amelyeket akcióterveikbe építve ellensúlyozhatják az olyan belső gyenge pontokat és a külső veszélyeket, mint:

- a finanszírozás bizonytalanságából eredő infokommunikációs lemaradás,

- a munkatársi kompetenciák avulása,

- a humánerőforrás utánpótlásának és megtartásának növekvő nehézségei,

- a szerzői jogi szabályozás problémái,

- a szabályozási környezet nehézkessége.

\section{A fejlesztés kulcsterületei}

\section{A gyűjtemények átértelmezése és fenntarthatóságuk biztosítása, a hozzáfé- rés segítése}

A felsőoktatási könyvtárak tartalmukban és történetiségükben különböző gyüjteményei kivételes, egyedi értéket képviselnek. A digitális információ megjelenésével és térhódításával, a dokumentum és a tartalom közötti határvonal elmosódásával, a beszerzett és helyben előállított tartalom együttélésével a gyüjtemények komplexitása megnőtt. A beszerzés, kezelés, megőrzés és szolgáltatás a könyvtár számára új kihívásokat jelent. A felhasználó azt várja el, hogy a számára szükséges, megfelelő funkcionalitással ellátott információhoz azonnal 
és egyszerüen hozzáférjen. A gyüjtemény magában foglalja a digitális vagy digitalizált tartalmakat is, függetlenül attól, hogy tulajdonolt, előfizetett vagy nyílt hozzáférésủ forrásokról van szó. Ezek hasznosulása függ a megtalálásukat segítő leíró adatoktól és a felhasználók információ-felhasználási készségeitől is. A könyvtárak előtt kettős feladat áll, a gyüjtemény fogalmának átértelmezése révén egyszerre kell biztosítani a kiválasztott dokumentumok hosszú távú megőrzését, továbbá a hozzáférés és a ráépülő szolgáltatások optimalizálását.

Mindezzel összhangban a következő föbb feladatok sorakoznak:

- a gyüjtemények feltártságának és láthatóságának növelése az együttmüködést támogató korszerü könyvtári platform megvásárlásával és az átállás megvalósításával,

- a kiválasztott nyomtatott, kéziratos és digitális gyüjteményrészek megörzése az intézményi és nemzeti céloknak megfelelően,

- digitalizálás a tartós megőrzés és a széles körü hozzáférés érdekében a Közgyüjteményi Digitalizálási Stratégia alapján,

- az egyetemeken elérhető ingyenes és előfizetett digitális tartalmak használatának elősegítése a szabványos kereshetőség javításával, a célközönséget elérő közösségi platformokon is, korszerủ eszközökre optimalizált formában,

- az egyetemi digitális tartalomfejlesztés támogatása, a tartalmak szolgáltatása,

- a könyvtárak által épített digitális gyüjtemények integrálása nemzeti és nemzetközi tartalomszolgáltató rendszerekbe,

- digitális kompetenciák fejlesztése.

\section{Kutatástámogatás, tudásmenedzsment, a tudományos eredmények dissze- minációja}

Az egyetemi könyvtárak alapfeladata a kutatási folyamat támogatása. Jelenleg ennek fontos tevékenysége az oktatói publikációs adatok központilag szabályozott kezelése a Magyar Tudományos Mủvek Tárában. Emellett segítik a kutatókat az egyéni és intézményi értékelések előkészítésében, publikációs stratégia kidolgozásában, a megváltozott tudományos információs piacon való eligazodásban, publikációik közzétételében.

Az intézményi tudásmenedzsment magában foglalja az intézményekben keletkezett tudományos eredmények, valamint az intézményi és egyéni kutatói profilok láthatóvá tételét. A hangsúly fokozatosan eltolódik a tudományos információ gyüjtése mint könyvtári feladat felől a tudományos információ és eredmények szétsugárzása felé.

A nyílt hozzáférés és a nyitott tudomány terjedésével, a tudományos teljesítmény értékelésének változásával a könyvtáraknak új feladataik keletkeznek. 
Ilyenek többek között a kutatási adatok, adathalmazok kezelésének segítése, az eredmények és a kutatási adatok újrahasznosításának ösztönzése, a tudományos kommunikáció átláthatóságának támogatása, a tudomány és a civil szféra közötti kapcsolat mélyítése.

Ezen a téren a főbb feladatok:

- nyílt hozzáférésü közzétételi csatornák (repozitóriumok, OA folyóiratok) müködtetése és népszerüsítése,

- az intézményi repozitóriumok mint az elektronikus nemzeti kutatási infrastruktúra elemeinek beépítése a kutatási ciklusba, összehangolása a kialakítandó intézményi kutatási információs rendszerekkel (CRIS),

- az új szemléletü kutatásmenedzsment támogatása a tudományos kommunikáció új formáinak bemutatásával és népszerüsítésével (nyílt hozzáférés, közösségi lektorálás, közösségi médiumok használata, alternatív hatásmérési módszerek stb.),

- a nyílt hozzáférés piaci modelljének követése és alakítása az átláthatóság és méltányosság irányába (a közzétételi díjak csökkentése, hatékony fizetési módok, kiadói kettős haszonszerzés elkerülése stb.),

- a kutatási adatkezelés támogatása, kutatási adatok láthatóságának és felhasználhatóságának népszerüsítése,

- etikus és felelős kutatási modellek és magatartás támogatása.

\section{A hallgatói eredményesség támogatása, tanulástámogatás}

A tanulás helyszínei és támogatói a könyvtárak. A korszerü felsőoktatásban nemcsak a tanulási terek, hanem az oktatási és tanulási formák, módszerek is átalakulóban vannak. Olyan oktatási módszerek terjedésének vagyunk tanúi és támogatói, mint a személyes igényeket és a tanulási eredményeket is figyelembe vevő adaptív tanulás, a hibrid oktatás vagy a felfedezésen alapuló és problémamegoldó oktatási modell. A hallgatók saját mobileszközeikkel és alkalmazásaikkal kívánják elérni a tartalmakat. A könyvtáraknak ehhez igazodva kell átalakítaniuk fizikai tereiket és információtechnológiai infrastruktúrájukat, alkalmassá téve azokat a hallgatók egyéni és csoportos feladatmegoldásának, valamint a gyakorlat- és problémaorientált tanulás hatékony támogatására, illetve az egymással és az oktatókkal való konzultáció számára is.

A Fokozatváltás a felsőoktatásban címủ felsőoktatási stratégia kiemelt feladatként határozza meg a hallgatói sikeresség növelését. Az irodalom közrebocsátása mellett a könyvtárosoknak egyre több segítséget kell adniuk a hallgatóknak az információs források közötti eligazodáshoz, sőt bizonyos hiányzó tanulási készségek elsajátításához is. Szervezett oktatással és személyre szabott tanácsadással segíthetik öket az egyre nagyobb önállóságot feltételező tanulási 
feladatokban, az információ kereséséhez és felhasználásához szükséges készségek fejlesztésében.

Az egyetemekkel szembeni igények - többek között a külföldi hallgatók arányának növekedése - fontos feladatokat (mint például a támogató szolgáltatások bevezetése) rónak a könyvtárra, és általában a campus-élet minőségét befolyásoló szervezetre is. Ehhez kapcsolódik a mind a Digitális Oktatási Stratégiában, mind a Fokozatváltásban kijelölt cél is, hogy az intézmények biztosítsanak akadálymentes épületet és informatikai infrastruktúrát az egyetemi közösségeknek.

Magyarország számára rendkívül fontos, hogy a hallgatók magas szinten tanuljanak meg idegen nyelveket, illetve sajátítsák el a szaknyelvet. A könyvtár mint tanulási tér a gyakorlásigényes nyelvtanulás természetes helyszíne, ezért rendelkeznie kell a megfelelő nyomtatott és digitális anyagokkal és alkalmazásokkal. Célszerü kialakítani a multimédiás nyelvi és a különböző átvihető készségek, digitális kompetenciák (informatikai készségek, infografika, video- és prezentáció-készítés stb.) fejlesztését támogató ún. „skill” laborokat is.

Ennek megvalósítása érdekében feladatok:

- az interdiszciplináris és problémamegoldó gondolkodásra és teamekben való munkára felkészítő oktatás támogatása az oktatói közösséggel együttmúködve: információfelhasználási és egyéb speciális tréningek nyújtása, ráépülő egyéni és csoportos konzultációval,

- a tanulási készségek fejlesztését szolgáló személyre szabott tanácsadás annak érdekében, hogy a hallgatók meg tudjanak felelni a felsőoktatásban megnövekedett kimeneti követelményeknek,

- a hallgatói sikerességet és a forráshasználatot támogató online segédletek és e-learning rendszerbe illeszthető digitális tanulási objektumok kidolgozása,

- az információkereső kompetenciák fejlesztését és a publikációk, hivatkozások formai követelményeit bemutató, tantervbe illesztett kredites képzések indítása,

- az aktív, problémaorientált, csoportos tanulást támogató rugalmas könyvtári terek (ún. skill lab-ek) kialakítása és müködtetése az adott egyetem sajátosságaihoz igazodva,

- a korszerü nyelvoktatást szolgáló nyelvi laborok kialakítása, és az ezt támogató digitális gyüjtemény szolgáltatása,

- akadálymentes épület- és informatikai infrastruktúra megteremtése a könyvtári terekben és az elektronikus szolgáltatásokban,

- a felsőoktatásban keletkező hallgatói dolgozatok, szakdolgozatok értékelését megkönnyítő, közös adatbázis alapján müködő plágiumdetektáló alkalmazás bevezetése az egész magyar felsőoktatásban. 
A kulcsterületeken felvázolt fejlesztési célokat és feladatokat megfelelő közvetítő eszközök és mechanizmusok alkalmazásával lehet elérni, melyek legföképpen a korszerü vezetés, a szervezeti kultúra tudatos átalakítása és a hatékony kommunikáció.

\section{Vezetés, szervezeti kultúra, szakértelem}

A könyvtárakban lezajló mélyreható változások nyomán felértékelődőben van a könyvtárosok szakértelme, különféle kompetenciái, mint a szolgáltatások alapja. A változásokra dinamikusan reagáló, a jövőt előre vetítő könyvtári stratégia kidolgozása innovatív gondolkodásmódot, vezetési filozófiát és gyakorlatot igényel. A kreatív gondolkodás ösztönzése, a megfelelő szakértői és vezetői utánpótlás kinevelése a siker alapvető feltétele. A vezetői tevékenység fontos része a szervezeti kultúra tudatos alakítása, ami a korábbi kihívásokra adott sikeres válaszok beépülésével alapozza meg a továbblépést, a szolgáltatások releváns átalakítását. A megfelelő szakmai kompetenciák megszerzése, a munkatársi gárda folyamatos fejlesztése, átképzése és diverzifikálása nélkül a könyvtárak nem tudnak megfelelni az igényeknek, mindez azonban feltételezi a bérezési rendszer átalakítását, az elérhető jövedelmek jelentős emelését.

Főbb feladatok e területen:

- a szükséges szaktudást és kompetenciákat, a továbbképzési szükségleteket felmérő, a könyvtári munkaerő-utánpótlást biztosító és az egyéni pályaépítést is támogató humánpolitika kidolgozása, javaslattétel a kormányzat felé az ezt támogató szabályozási környezet és versenyképes bérezés kialakítására,

- a könyvtárosképzés tartalmi megújításának segítése,

- az egyéni és szervezeti egység szintü teljesítményértékelés rendszerének kidolgozása, alkalmazása a kiváló teljesítmények ösztönzésére és elismerésére, teljesítményelvű bérezés lehetőségének megteremtése,

- könyvtári minőségbiztosítási rendszer müködtetése és fejlesztése,

- hatékony és rugalmas munka- és folyamatszervezési modellek kidolgozása,

- kompetenciafejlesztés változatos eszközrendszerrel, a folyamatos tanulás szükségességének elismertetése, finanszírozási források hozzárendelése.

\section{Kommunikáció, márkaépítés}

A könyvtárak tevékenységének értékét nem a látogatószám vagy a kölcsönzött kötetek száma mutatja, hanem az, hogy hogyan segítik a fenntartó intézmény és a szélesebb társadalmi környezet sikerességét. Ezt, és a szolgáltatásaikban rejlő további lehetőségeket kell bemutatniuk minden belső és külső érintettnek. 
Fontos, hogy a „könyvtár mint márka” értékét megőrizve az újfajta szolgáltatások minél szélesebb körben váljanak ismertté, enyhüljenek a könyvtárakkal kapcsolatos sztereotípiák. A használói visszajelzések megfontolása, a felhasználókkal/érintettekkel folytatott folyamatos kommunikáció és aktív marketing minden fejlesztés alapja.

Feladatok:

- jól müködő kommunikációs csatornák kialakítása a fenntartó és az egyes felhasználói körök irányába,

- jelenlét az egyetemi közösséget és a tudomány népszerüsítésének célközönségét is elérő közösségi hálózatokon,

- a könyvtári szolgáltatások eredményességének hazai és nemzetközi bemutatása médiamegjelenésekben, konferencia-részvételek révén,

- partnerkapcsolatok kiépítése és erösítése a könyvtárak müködésében érintettekkel (felhasználói csoportok, szervezetek, cégek stb.),

- a használói és munkatársi szokások és elégedettség rendszeres monitorozása korszerü módszerekkel, az eredmények értékelése és kommunikációja,

- kompetenciafejlesztés a kommunikáció és marketingtevékenység terén.

Összefoglalásképpen megállapítható, ahhoz, hogy a felsőoktatási könyvtárak folyamatosan átalakuló szerepük mellett eredményesen lássák el oktatási és kulturális feladataikat is, elengedhetetlen:

- az egymással és más érintettekkel kiépített partneri együttmüködés,

- a fenntartóval folytatott párbeszéd és visszacsatolás,

- a közép- és hosszú távú célok és feladatok meghatározása,

- a stabil és egyenletes jogi és finanszírozási környezet fenntartása.

\section{Rezümé}

A magyar felsőoktatási könyvtárak felvázolták azokat a fejlesztési irányokat és tennivalókat, amelyek a következő néhány évben leginkább szolgálják a magyar felsőoktatás és tudományos kutatás támogatását. Az alapértékek, a küldetés és a jövőkép megfogalmazása után különféle technikákkal végzett helyzetelemzés és a kormány által elfogadott nemzeti stratégiák számbavétele alapján történt meg a fejlesztés kulcsterületeinek kijelölése. Ezek a következők:

- a digitalizálást és a nemzeti kulturális örökség megőrzését is magában foglaló gyüjteményépítés,

- a nemzetközi hálózatokba beágyazott magyar tudomány támogatása,

- a felsőfokú oktatás és a hallgatói eredményesség előmozdítása. 
Mindez a humánerőforrás fejlesztésével, korszerü vezetési és szervezeti kultúra kialakításával, tudatos kommunikáció és minőségmenedzsment révén érhető el, az egymással és más érintettekkel kiépített partneri együttmüködés, a fenntartóval folytatott párbeszéd és visszacsatolás, illetve a stabil és egyenletes jogi és finanszírozási környezet megléte esetén.

\section{Scholarship and education in the digital era. Strategic directions of Hungarian academic libraries 2018-2023}

Hungarian academic libraries outlined the strategic directions and objectives that best support the evolving needs of Hungarian higher education and scholarly research. After defining the core values, mission and vision of libraries, they performed an internal and external environmental analysis to help identify the strategic priorities and key areas for actions:

- Collection development including collaborative digitisation and the preservation of the national cultural heritage.

- Research support in an increasingly international and networked research landscape.

- Enhancing educational goals and student success.

To achieve these objectives a highly-skilled and diverse library workforce is needed. Showing leadership, promoting an open and innovative organisational culture and rewarding high quality performance will help academic libraries remain relevant. A solid legal and financial environment, partnership and collaboration with all stake holders are key to success.

NAGY ZsUZSANNA

föigazgató

Budapesti Corvinus Egyetem Egyetemi Könyvtár

ORCID: 0000-0002-1727-1785 